\title{
Physical Growth and Motor Development of 5th Grade Students on Sub-district Pituruh Purworejo
}

\author{
Hermawan Pamot Raharjo ${ }^{1}$, Fera Andriyani ${ }^{2}$ \\ \{hermawan_pamot@mail.unnes.ac.id ${ }^{1}$, feraandriyani6@gmail.com ${ }^{2}$ \} \\ Universitas Negeri Semarang, Semarang, Indonesia ${ }^{1,2}$
}

\begin{abstract}
This research to determine the level of physical growth and motor development on $5^{\text {th }}$ grade students SD Negeri in Pituruh District Purworejo. Descriptive quantitative research design was used. The sampling technique used Simple Random Sampling. Total respondent were 142 students. The study showed that physical growth and motor development were very thin; thin; normal; over weight; obese were $3(2 \%) ; 26$ (18\%); 98 (69\%); 13 (10\%); 2 $(1 \%)$, respectively. The motor development were excellent category; good category; medium category were 7 (5\%); 32 (23\%); 64 (46\%), respectively. In the category of less than 37 students $(26 \%)$, and in the category of very less as many as 2 students $(1 \%)$. The conclusion was stated that physical growth in the $5^{\text {th }}$ grade elementary school in Pituruh District were in the normal category and moderate category for the level of motor development.
\end{abstract}

Keywords: physical growth, motor development, elementary school

\section{Introduction}

Growth and development of movement in children is a condition where at the age of elementary school is very important in influencing the continuity of learning, especially in physical education learning. Growth is a process of improvement in terms of the size that occurs in someone who is quantitative. While development is a process of changing the ability of work organs and changes in functional capacity towards more organized [1].

Growth and development in children can be measured quantitatively and qualitatively, meaning that quantitative measurements can measure growth that can be seen visibly in the presence of differences such as height, weight, whereas measurements in child development that are not visible invisible but with certain criteria can measure motor development, for example cognitive development and motor development of children. Measuring the growth and development of children is done to see whether children already have the ability or growth in accordance with criteria in their age as an evaluation to give meaning to the results that have been achieved. 
Growth and development of children is a complex matter, where many factors are influential and interconnected. The influencing factors are internal factors such as age, sex, heredity, nutrition, history of disease, as for external factors such as the environment, physical activity, food, etc [2].

In addition to some of the factors above regarding growth and development in each individual, of course there are significant differences, this is influenced by differences in the fundamental character of children, for example, during school learning hours there are children who are very active in participating in physical education and are fond of physical activity, conditioned there are other children who are lazy in doing the movement because of hot weather conditions or there are other things. This is very influential on the level of child development.

Childhood is a time when children love to play. This is often found when outside school hours or after school after school children spend more time playing. Like playing bicycle, running around, playing soccer which is usually done by many boys. Unconsciously that the activity will affect the child's motor development. However, as technology develops that children prefer to play online, this causes children's life patterns to turn into lazy and passive moves.

Physical growth is very closely related to the motor development of children. Motor is a development of controlling body movements through coordinated activities between the nervous system, muscles and brain. In motor development there is a relation with motor skills both fine and gross motor skills. A child's gross motor skills need to be trained and developed at all times with various activities. This development allows a child to do things better, including academic and physical achievements.

From the data of the researchers' initial observations, it is known that the conditions in the field indicate that the physical growth of elementary school students can be seen visibly with a difference, whereas in gross motor development in students there is indeed a difference between one individual and another, this is triggered by physical activity carried out by students who are different from each other, for example when playing, it can be seen that some children actively play outside the learning hours, some other children are busy with their respective activities such as just sitting around in groups, there are those who are engrossed in enjoying food, some who prefer to read books and so on. This affects the motor skills of children, children who tend to be active in sports or physical activities will certainly be different from children who rarely do physical activities both within the school environment and outside the school environment. So that the physical growth and motor development of elementary school students can run well, students are expected to frequently perform basic movements or perform physical activities [3].

The problems discussed are How Big is the Physical Growth Rate and Motoric Development of Elementary School Children in Class V in Pituruh District, Purworejo Regency. The purpose of this study was to determine how much the level of Physical Growth and Motoric Development of Elementary School Children in Class V of Pituruh Subdistrict, Purworejo Regency. 


\section{Methods}

\subsection{Research design}

The method used in this study is a survey test and measurement of physical growth and motor development. The research subjects were students of Class V Public Elementary Schools in Pituruh Subdistrict, Purworejo Regency. The sample came from 10 schools with a total of 142 students, to determine the school by lottery.

\subsection{Research instruments}

The instruments used were the Anthropometric Test and the Motor Ability Test [4]. This test has a reliability of 0.93 and validity of 0.87 . The tests include: (1) Anthropometric tests: Measurement of height and measurement of weight; (2) Motor Ability Test: Agility test (4x10 meter shuttle run), Ball throwing test (Coordination), Balance Test, Speed test.

\subsection{Data analysis technique}

Data analysis techniques used in quantitative research that are used are clear, which is directed to answer the problem formulation or test the hypothesis that has been formulated [5]. Then the data analysis technique uses the static methods that have been available. Data analysis is a percentage and then the results are described.

\section{Results and discussions}

Data on physical growth of students in terms of BMI (body mass index), it can be seen on table 1 and Fig 1, that of the 142 students consisting of 3 students (2\%) included in the category of "very thin", "thin" category 26 students (18\%), "normal" category "98 students (69\%), in the" fat "category of 13 students (10\%), and in the" obesity "category by 2 students $(1 \%)$.

Table 1. Description of physical growth.

\begin{tabular}{llll}
\hline Categories & Interval & Frequency & Percentage \\
\hline Very thin & $<-3$ SD & 3 & $2 \%$ \\
Thin & -3 SD to <-2 SD & 26 & $18 \%$ \\
Normal & -2 SD to1 SD & 98 & $69 \%$ \\
Fat & $>$ 1SD to2 SD & 13 & $10 \%$ \\
Obesity & $>$ 2 SD & 2 & $1 \%$ \\
Total & & 142 & $100 \%$ \\
\hline
\end{tabular}




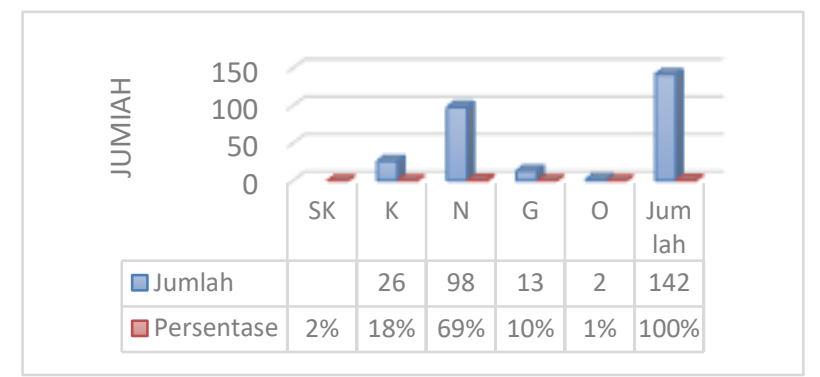

Fig. 1. Physical Growth.

The results of the number of 142 students in motor development students can be seen on table 2 and Fig. 2, consisted of 7 students (5\%) had motor development in the excellent category, good category 32 students $(23 \%)$, medium category 64 students $(46 \%)$, in the category of less 37 students $(26 \%) \%)$, and very few categories as many as 2 students (1\%).

Table 2. Description of motor development.

\begin{tabular}{llll}
\hline Categories & Interval & Frequency & Percentage \\
\hline Very good & $\geq 229,17$ & 7 & $5 \%$ \\
Good & $209,72-229,16$ & 32 & $23 \%$ \\
Medium & $190,27-209,71$ & 64 & $45 \%$ \\
Low & $170,82-190,26$ & 37 & $26 \%$ \\
Very low & $\leq 170,81$ & 2 & $1 \%$ \\
Total & & 142 & $100 \%$ \\
\hline
\end{tabular}

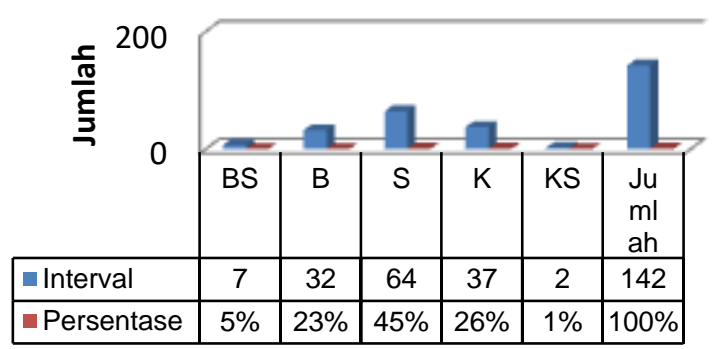

Fig. 2. Motor development.

From the results of the study showed that physical growth in terms of body mass index showed a dominant result that is normal. At the age of primary school on physical growth both men and women begin to experience significant growth this will continue to develop according to age. Children said to be normal means that the pattern of food consumption such as the nutritional intake received by children already fulfilling offspring also affects the level of physical growth in children [6]. 
For physical growth at primary school age can be influenced by other factors such as age, gender, illness, economic conditions, living environment, etc. In motor development from the results of the study showed that the results obtained are moderate. This relates to physical activities carried out by each student both during Physical Education hours and outside school hours. Other factors that can affect physical activity are environmental factors, especially in the school environment also affect student activities when students do activities at school. Lack of adequate facilities and infrastructure is also an obstacle for students to be able to carry out activities optimally. For example, the condition of the field or playing equipment will affect the activities of children, so that children's school space is limited and not optimal. Outside the school environment (residence) also affects the level of motor development of children [7].

The majority of students at leisure or after school hours are widely used for leisure and only a few students who often do physical activity (exercise). In addition, with the development of technology, causing students to use it more excessively, this has become one of the factors causing the low level of students doing physical activities. the habit of children playing games, watching TV [8].

This study only confirms that physical growth and motor development are very influential on the continuity of students in learning physical education and influential in achieving student achievement, for that it needs to be considered in the process of growth and development of children.

\section{Conclusion}

The conclusion of the study was that physical growth in the fifth grade elementary school in Pituruh District was included in the "normal" category and for the level of motor development included in the "moderate" category.

\section{References}

[1] Ardiansyah, F. (2016). Kemampuan Motorik Dasar Siswa Kelas IV dan V SD N Keraton Yogyakarta Tahun Ajaran 2015/2016. PGSD Penjaskes, (6).

[2] Arikunto, Suharsimin. (2010). Prosedur Penelitian Suatu pendekatan Praktik. Jakarta: Rineka Cipta.

[3] Kementerian Kesehatan. (2010). Keputusan Menteri Kesehatan Republik Indonesia. Jakarta: Direktorat Jenderal Bina Gizi dan Kesehatan Ibu dan Anak, Kementerian Kesehatan RI.

[4] Mahayaty, L. (2014). Studi Tentang Faktor- Faktor Yang Mempengaruhi Pertumbuhan Dan Perkembangan Pada Balita Di Desa Pengalangan RW 03 Menganti Gresik. Jurnal Keperawatan, 3(1).

[5] Nurhasan, 2000. Tes dan pengukuran pendidikan olahraga. Online available at https://id.scribd.com/doc/302333652/Tes-Dan-Pengukuran-Pendidikan Olahraga-DrsNurhasan-m-pd.

[6] Sugiyanto. 2008. Perkembagan dan Belajar Motorik. Jakarta: Universitas terbuka.

[7] Sugiyono. 2010. Metode penelitian pendidikan. Bandung: Alfabeta.

[8] Syarifudin. (2010). Tes Prestasi Fungsi dan Pengembangan Pengukuran Prestasi Belajar. Yogyakarta: Pustaka Pelajar. 